\title{
Total Quality Management (TQM) Practices toward Product Quality Performance: Case at Food and Beverage Industry in Makassar, Indonesia
}

\author{
Musran Munizu ${ }^{1}$ \\ ${ }^{I}$ (Faculty of Economics Business, Hasanuddin University, Makassar, Indonesia)
}

\begin{abstract}
The purpose of this research was to test and analyze the effect of TQM practices impelementation which consists of leadership, strategic planning, customer focus, information and analysis, people management, and process management to product quality performance. The population were 108 food and beverage companies in Makassar, Indonesia. Respondents are production managers or operation managers. Sample technique which used is population sampling. Method of analysis which use both descriptive statistic and Structural Equation Modelling (SEM). Data processing uses two statistic tools i.e: IBM SPSS and AMOS 19.00. The findings of research indicate that leadership has significant effect on product quality performance, strategic planning has significant effect on product quality performance, customer focus has significant effect on product quality performance, information and analysis has significant effect on product quality performance, people management has significant effect on product quality performance, and process management has significant effect on product quality performance. Leadership factor has dominant effect on product quality performance (critical ratio $=9.760>t$-table $=1.960$; and probability $=0.000<\alpha=0.05$ ).
\end{abstract}

Keywords: TQM Practices, Product Quality Performance, Operation Management

\section{Introduction}

In the globalization era, quality is the most important element as competitive source in every company or industry. The fastest change in the competitive business environment to drive many enterprises to create both innovation and ability to win the competition in the domestic and international market. Today, in order still exist in marketplace, companies should adopt and implement the management best practices in operation management, i.e: total quality management (TQM) and Supply Chain Management (SCM) (Heizer and Render, 2004). These practices can help organization to identify change in the dynamic environment and to respond proactively through continuous improvement activity in operation functions to achieve best performance (Chase et al., 2005).

The challenges in improving the performance in competition era are continuous improvement of business activities which focused on customers, flexibility and quality. Therefore, the management of quality should be done by companies in order to increase their market and to win the competition. Companies couldn't be able to manage the change would be decline gradually in marketplace.

Conceptually, quality is the totality of the shape and characteristics of the goods or services that demonstrate its ability to satisfy the needs of its apparent and hidden (Heizer and Render, 2004). Some experts define quality with a variety of interpretations. Juran (1989) defines quality as fitness for use. This definition includes product features that meet the needs of consumers and free from deficiencies. While Deming found the quality is meet the needs and expectations of consumers based on over the price they have paid. Deming's philosophy of building quality as a system (Bhat and Cozzolino, 1993). General define of quality by Bina Produktivitas Tenaga Kerja (1998) are: (1) a perfect degree that contains a comparative understanding of the product level (grade) specific, (2) The level of quality that contains the notion of quality to evaluate technical, and (3) suitable for use, the ability of the product or service in delivering satisfaction to customers.

Heizer and Render (2004) found that quality primarily affects companies in four areas: 1) cost and market share: an improved quality can lead to increased market share and cost savings, they can also affect profitability, 2) corporate reputation: reputation company follows a quality reputation produced. Quality will appear along with the perception of the company's new product, employee management practices, and relationship with suppliers; 3) product liability: organizations have a great responsibility for all resulting from the use of goods or services, and 4) the international implications: in the age of technology, the quality is a concern of international operations.

In order companies to compete effectively, products and services must meet the desired quality and price. In fact, quality is a concept that is quite difficult to be understood. Today, the word of quality has varied interpretations. It can not be defined as a single phrase, because it based on the context. 
One form of best management practices in the company is Total Quality Management (TQM). Since the early 1980's TQM has received the most attention from the managers, because it can help managers to improve the company performance. Total Quality Management (TQM) is a new paradigm in doing business. TQM attempts to maximize the competitiveness of the organization through focus on customer satisfaction, employee involvement, and continuous improvement of the quality of products, services, people, processes and organizational environment (Krajewski et al., 2003).

According to Sila et al. (2007) total quality management (TQM) plays a very important role in enhancing the strength of enterprises competitiveness. In the global market that continuously changing both speed of delivery and product quality are the essential elements for companies to compete in marketplace. TQM is an approach that should be done many organizations to improve the quality of products, reduce production costs and increase productivity. Implementation of TQM have a positive impact on revenue and production costs (Gaspersz, 2005). Other evidence also suggests that companies that pursue best practices of TQM to achieve higher profits and shareholder value as well greater cashflows (Corbett and Rastrick, 2000).

Performance measurement is an important factor for effective management. In general, performance is defined as the extent to which an operation meets performance objectives, and major steps in order to meet customer needs. The evidence suggests that without performing a measurement of the performance, managers are very difficult to fix it. Therefore, improving the organizations performance should begin from identification some variables that influence of performance and measure it accurately. Measurement of quality performance is essential for many organization, in order to achieve both operation efficiency and optimal business performance (Demirbag et al., 2006).

Organizational performance can be measured in two dimensions, namely operational performance or quality performance and organizational performance. Operating performance reflects the performance of the internal operations in terms of cost and waste reduction, product quality improvement, new product development, delivery performance improvement, and increased productivity. Indicators and variables are considered as a major factor because they follow directly from the actions taken in the company's operations, while the performance of an organization is measured by financial measures such as revenue growth, net income, the ratio of profit to revenue and return on assets (ROA), and non-financial measures such as investment in R\&D, and the capacity of companies to develop a competitive profile (Brah and Lim, 2006).

Empirical studies linking between TQM and performance have been carried out by previous researchers. For example, Rahman (2001) conducted a study of 53 Australian SMEs and found that the critical success factors of TQM implementation are leadership, strategy and planning, employee empowerment, employee engagement, employee training and development, information and analysis, and customers management. Demirbag et al. (2006) conducted an empirical study to identify the critical factors success of TQM of SMEs in Turkey. The results show that there were seven CSFs of TQM practices i.e: the quality of data and reporting, the role of top management, employee relations, supplier quality management, training, quality policy and management process. Then, Prayogo and Hong (2008) conducted a study on 130 Industrial Manufacturing Research and Development in Korea. They found that the implementation of TQM has significant effect on performance. Furthermore Prayogo and Brown (2004), Prayogo and Dermott (2005), and Salaheldin (2009) found that the practices of TQM implementation affect the overall performance of the company both financial and non financial performance.

Based on the description above, the purpose of the study are to analyze the effect of practices of Total Quality Management (TQM) to product quality performance based on product/operation managers in food and beverage companies in Makassar, Indonesia.

\subsection{Conceptual Framework}

\section{Conceptual Framework and Hypothesis}

To determine critical factors of total quality management, various studies have been carried out and different instruments were developed by individual researchers and institutions such as Malcolm Baldrige Award, EFQM (European Foundation For Quality Management), and the Deming Prize Criteria (Munizu, 2002). Based on these studies, a wide range of management issue, techniques, approaches, and systematic empirical investigation have been generated. Conceptually, The level of product quality is determined by the implementation of TQM practices in the company. Based on the above, the conceptual framework of this research could be presented as follows. 


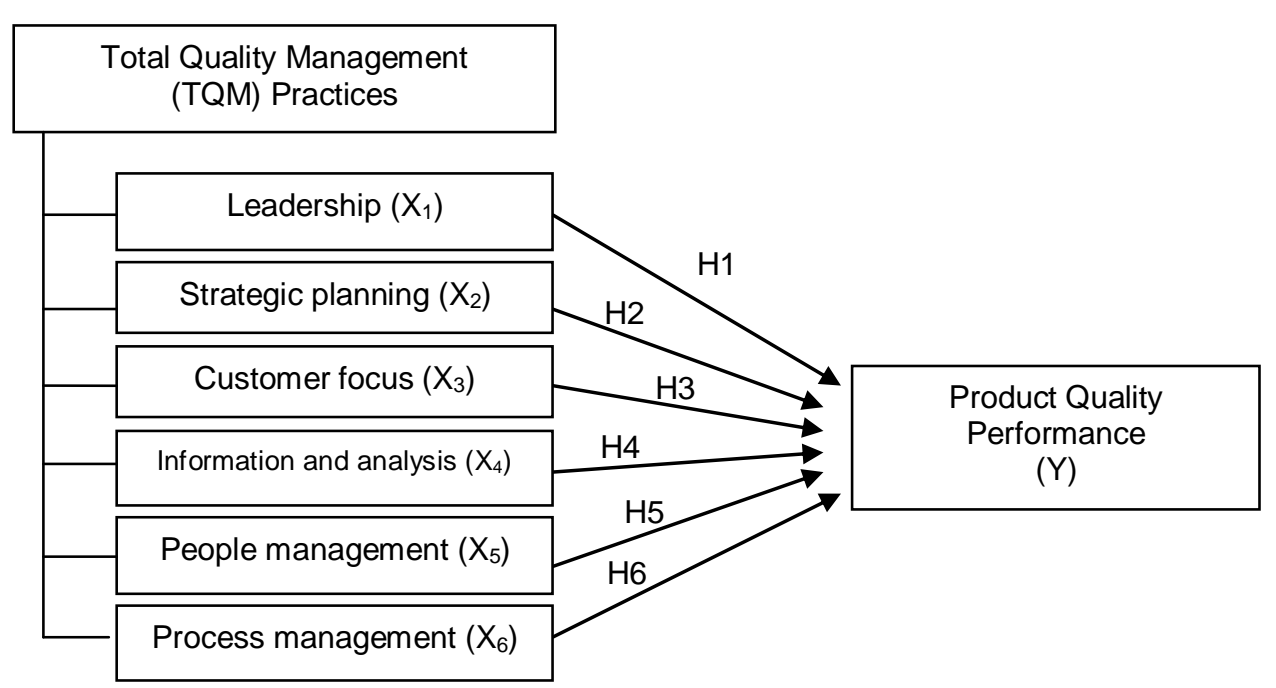

Figure 1. Conceptual Framework

\subsection{Research Hypothesis}

H1: The leadership has significant effect to product quality performance.

$\mathrm{H} 2$ : The strategic planning has significant effect to product quality performance.

$\mathrm{H} 3$ : The customer focus has significant effect to product quality performance.

H4: The information and analysis has significant effect to product quality performance.

H5: The people management has significant effect to product quality performance.

H6: The process management has significant effect to product quality performance.

\subsection{Variable Identification and Measurement}

\section{Research Methodology}

Variables in this study consist of: (1) practices of TQM are: leadership, strategic planning, customer focus, information and analysis, people management, and process management as exogenous variables, and (2) product quality performance as endogenous variable. Variables of TQM practices adopts a model which is developed by Prayogo and Brown (2004), and Prayogo and Dermott (2005). While the product quality performance is adopted by the Australian and New Zealand manufacturers (AMC, 1994), in (Corbett and Rastrick, 2000). Respondents were asked to provide responses to each item, and each item was assessed by a Likert scale assessment with intervals score: 1 (strongly disagree), 2 (disagree), 3 (Neutral), 4 (agree) and 5 (strongly agree) (Sugiyono, 2008)

\subsection{Population and Sample}

Population of the research is food and beverage companies in Makassar, Indonesia. The number of population is 108 companies (BPS Makassar, 2011). Sample was collected using population sampling or census. This technique was chosen with the consideration that the number of population is relatively small, that is 108 companies. Cooper and Emory (1999), Sekaran (2007) and Sugiyono (2008) state if the number of population is smaller than 100, population sampling or census is the better sampling technique. So, the number of population is the same as sample. The respondents are production managers or operation managers. The consideration for determining these respondents is that directors or managers of a company would have a detailed knowledge both condition of the firm and the implementation of TQM practices.

\subsection{Data collection}

Data was collected by a survey which was carried out in its entirety in one short study or in a cross sectional study through questionnaire. The distribution of questionnaire to 108 food and beverage companies in Makassar, Indonesia. Until the end of the data collection period, the number of questionnaire returned was 108 or equivalent to $100 \%$ of the total number of companies in the sample. Questionnaire was distributed by direct visit to the company premises to explain the purpose of the questionnaire and require for answer concerning when the filled questionnaire can be retrieved from the company.

\subsection{Data Analysis}

Descriptive statistics is used to provide an overview the demographics of survey respondents, as well as a description of research variables without generalizing. While, the inferential statistics is used to test the 
hypothesis in a study. Hypothesis test in this study using the analysis of Structural Equation Modeling (SEM). Data is processed by IBM SPSS and AMOS version 20. According to Hair et al. (1998) and Ferdinand (2002) research model could be said a fit model, if it meets the conditions as follows.

Table 1. Goodness of Fit Indices (GFI) for Model Evaluation

\begin{tabular}{|l|c|}
\hline \multicolumn{1}{|c|}{ Goodness of Fit Index } & Cut off Value \\
\hline Chi square & small value expected \\
\hline Significance Probability & $\geq 0.05$ \\
\hline RMSEA & $\leq 0.08$ \\
\hline GFI & $\geq 0.90$ \\
\hline CMIN/DF & $\leq 2.00$ \\
\hline TLI & $\geq 0.95$ \\
\hline CFI & $\geq 0.95$ \\
\hline
\end{tabular}

Source: Hair et al. (1998); Ferdinand (2002)

\subsection{Research Findings}

\section{Research Findings and Discussion}

Respondents of this study have quite different characteristics. Diversity can be seen from the personal data of respondents including sex, age, position, and educational level in the organization. A total 108 respondents which participated in this study. The majority of respondent who participated in this research was male gender (92\%), aged between 30 to 40 years (72\%), having position within the company as a production manager and operations (88\%), and having level of education bachelor degree/S1 (70\%), and master (25\%).

Furthermore, the research variables which is tested in this study consists of two variables, namely total quality management (TQM) practices, and product quality performance. Respondents answer each item on the TQM practices variables i.e: leadership, strategic planning, customer focus, information and analysis, people management, and process management.

Completely the level perception of respondent on variables or constructs could be seen from mean value of items or indicators as follows

Table 2. Results for mean value of research variables

\begin{tabular}{|c|l|c|c|}
\hline No. & \multicolumn{1}{|c|}{ Variables } & Mean & Description \\
\hline 1. & Leadership & 4.25 & Very high \\
\hline 2. & Strategic planning & 4.10 & High \\
\hline 3. & Customer focus & 3.82 & High \\
\hline 4. & Information and analysis & 4.00 & High \\
\hline 5. & People management & 3.65 & High \\
\hline 6. & Process management & 3.28 & Enough \\
\hline 7. & Product quality performance & 3.91 & High \\
\hline
\end{tabular}

Source: data processed

According to table, it could be reveals that average value (mean) of TQM practices variable was in high or good category. Leadership as the higher indicator than others (4.25), and process management as lower indicator (3.28). While, the product quality performance was in high or good category (3.91). Then, to test the hypotheses and produce a model fit use analysis of Structural Equation Modeling (SEM). Result of Goodness of fit indices (GFI) for the complete model that describes the relationship between each variable in the study can be presented in the following table.

Tabel 3. Result of Goodness of Fit Indices (GFI) Model

\begin{tabular}{|l|c|c|c|}
\hline & Cut off value & Model result & Description \\
\hline Chi-square & small value expected & 49.221 & Marginal \\
\hline Prob. & $\geq 0.05$ & 0.335 & good \\
\hline GFI & $\geq 0.90$ & 0.920 & good \\
\hline RMSEA & $\leq 0.08$ & 0.011 & good \\
\hline TLI & $\geq 0.94$ & 0.972 & good \\
\hline CFI & $\geq 0.95$ & 0.970 & good \\
\hline
\end{tabular}

Source: data processed 
The results of model calculations at final step use the criteria of goodness of fit a model as presented in the table above indicates a best model. So, it can be inferred that model in the studi is valid or acceptable. Then, the next step is conducting the analysis by look at the value of loading factor and probability (prob.) of each variable which is used. Completely results could be presented in the following table.

Tabel 4. Result of Final Model of SEM

\begin{tabular}{|l|c|c|c|c|}
\hline \multicolumn{1}{|c|}{ Variables } & $\begin{array}{c}\text { Loading } \\
\text { Factor }\end{array}$ & $\begin{array}{c}\text { Critical } \\
\text { Ratio }\end{array}$ & Prob. & Description \\
\hline $\begin{array}{l}\text { Leadership }---\rightarrow \text { product quality } \\
\text { performance }\end{array}$ & 0.864 & 9.760 & 0.000 & Significant \\
\hline $\begin{array}{l}\text { Strategic planning }---\rightarrow \text { product quality } \\
\text { performance }\end{array}$ & 0.414 & 6.925 & 0.002 & Significant \\
\hline $\begin{array}{l}\text { Customer focus }---\rightarrow \text { product quality } \\
\text { performance }\end{array}$ & 0.360 & 5.145 & 0.013 & Significant \\
\hline $\begin{array}{l}\text { Information and analysis }---\rightarrow \text { product } \\
\text { quality performance }\end{array}$ & 0.218 & 3.154 & 0.033 & Significant \\
\hline $\begin{array}{l}\text { People management }---\rightarrow \text { product quality } \\
\text { performance }\end{array}$ & 0.224 & 3.274 & 0.030 & Significant \\
\hline $\begin{array}{l}\text { Process management--- } \rightarrow \text { product quality } \\
\text { performance }\end{array}$ & 0.455 & 7.122 & 0.000 & Significant \\
\hline
\end{tabular}

Source: data processed

Based on the table, it can reveals that the relationship among variables have a significant relationship, because the probability $\leq 0.05$ and Critical Ratio (CR) $\geq 1.960$. The variables that has a significant effect (Prob. $\leq 0.05$ ), namely: (1) leadership toward product quality performance (0.000), (2) strategic planning toward product quality performance (0.002), (3) customer focus toward product quality performance $(0.013)$, (4) information and analysis toward product quality performance (0.033), (5) people management toward product quality performance (0.030), and (6) process management toward product quality performance $(0.000)$.

Based on the data and the information above, it can be concluded that the variables or constructs that have a dominant influence on product quality performance is leadership with loading factor of 0.864 and probability (prob.) of 0.000 .

\subsection{Discussion}

Based on the critical ratio and probability values as presented in the table, leadership has significant effect on product quality performance. Therefore, the first hypothesis which is proposed in this study supported by empirical facts. The results of this study support the previous studies that management commitment or leadership is one of the key elements of successful implementation of TQM (Rahman, 2001; Munizu, 2002; Demirbag et al., 2006). Leadership has to support the successful of TQM practices in order to achieve high performance. Product quality can be achieved through an integrated management system. This finding consistent with Prayogo and Brown (2004) and Prayogo and Dermott (2005) that leadership can improve the performance of product quality and performance of the organization.

Strategic planning has significant effect on product quality performance. Therefore, the second hypothesis proposed in this study proved or supported by empirical facts. The results of this study support Heizer and Render (2004), and Krajewski et al. (2003) that the strategic planning of the organization is absolutely necessary as a basic reference for controlling the quality improvement program. With the proper planning of the organization, the programs related to improving the quality of the product will be more focused and measurable, so that product quality performance can be improved continuously and sustainability in the future.

Customer focus has significant effect on product quality performance. Therefore, the thirth hypothesis proposed in this study proved or supported by empirical facts. The results of this study support the previous studies that customer focus is one of the key elements of successful implementation of TQM (Krajewski et al., 2003; Corbett and Rastrick, 2000; Prayogo and Brown, 2004, and Prayogo and Dermott, 2005). Focus on the consumer is one of the company's micro factors which is affecting the change and development of organizational performance and business performance (Demirbag et al., 2006; Brah and Lim, 2006).

Information and analysis has significant effect on product quality performance. Therefore, the fourth hypothesis proposed in this study proved or supported by empirical facts. The results of this study support the previous studies that the information and analysis with the help of tools (tools) statistic is one of the key elements of successful implementation of TQM (Krajewski et al., 2003; Corbett and Rastrick, 2000, and Prayogo and Dermott, 2005). Brah and Lim (2006) stated the several statistical tools are widely used by 
companies in controlling and improving the organizational performance. All aspects of statistical tools of quality are brainstorming, checklists, Pareto diagrams, fishbone diagram, flowcharts, control charts, scatter diagrams, and histograms.

Management people has significant effect on product quality performance. Therefore, the fifth hypothesis proposed in this study proved or supported by empirical facts. The results are consistent with the notion that empowerment and employee engagement is one of the key elements of successful implementation of TQM (Krajewski et al., 2003; Corbett and Rastrick, 2000; Munizu, 2002, and Prayogo and Brown, 2004). Some forms of employee empowerment efforts by the company, are: the establishment of a working group (Small Group Activity) or Quality Circles (QCC), periodic meetings, brainstorming, recognition and achievement awards for employees in improving and enhancing the quality. Empowerment and recognition of the existence of employee by the company has produces the effective way to build a quality culture and performance in organization.

Management process has significant effect on product quality performance. Therefore, the sixth hypothesis proposed in this study proved or supported by empirical facts. The results of this study support the Krajewski et al., (2003); Corbett and Rastrick, (2000); Prayogo and Brown, (2004), and Salaheldin (2009) that management process is one of the TQM elements that affect both product quality performance and business performance.

Therefore, the findings of the research can be a very useful input to management in evaluating the company's quality program. Evaluation of the quality program should be done regularly and routinely. In addition, Total Quality Management (TQM) should be understood deeply by management. TQM is not only a quality program in the field of company operation, but also TQM become an integrated part in organizational functions and the company's business strategy is to enhance the competitiveness as well as company performance. A deeply understanding of the TQM should include three essential elements which integrated each other, i.e : (1) philosophical elements, (2) generic tools, and (3) the tools of quality department at every organization.

\subsection{Conclusion}

\section{Conclusion and Suggestion}

Based on research findings and discussion, it can be concluded that TQM practices that consists of: (1) leadership, (2) strategic planning, (3) customer focus, (4) information and analysis, (5) management people, and (6) management process have significant effect on product quality performance. These findings indicate that the degree of increase or decrease in the product quality performance is determined by variables such TQM. Strong and consistent leadership with the successful implementation of TQM in the organization of the company has dominant effect in determining the performance of the quality of the product in food and beverage companies. Quality improvement programs that have been planned for the company within the framework of TQM practices could be work well if managers can be able to support it.

\subsection{Suggestion}

The management company should consider TQM practices variables in improving product quality performance such as leadrship, strategic planning, customer focus, and process management in product quality. Superior quality product will bring to the company's performance and sustainability competitive advantage in long run. Information and analysis, and management employees variable should get more attention, because of its implementation in the company is not optimal yet. Using statistical tools (SQC = statistical quality control), the provision of quality training to employees, creation of the task force, QCC (quality control group), and other quality instrument utilization must be optimized in order to deliver better results in supporting the achievement of best product quality performance.

This study shows some weakness, example the results only could be generalized to manufacturing industry especially at food and beverage industry in Makassar, Indonesia. So, for further research can develop this research by increasing the number of manufacturing company, the number of variables to be studied, and its applications to companies in other sectors, such as automotive and service industry.

\section{References}

[1] Heizer, Jay, and Barry Render. Operation Management, Seventh Edition (USA: Pearson Prentice Hall Inc., 2004)

[2] Chase, Richard B., Nicholas J. Aquilano, F. Robert Jacobs. Operation Management for Competitive Advantage (USA: McGrawHill, 2005)

[3] Juran, J.M. Juran on Leadership for Quality (The Free Press, USA: MacMillan, 1989)

[4] Bhat, V. and J. Cozzolino. Total Quality: An Effective Management Tool, Quality Management Journal,1993, 101-123

[5] Bina Produktivitas Tenaga Kerja. Manajemen Mutu Terpadu (Jakarta: Departemen Tenaga Kerja, 1998)

[6] Krajewski, J. Lee and P. R. Larry. Operations Management Strategy and Analysis, Fifth Edition, (USA : Addison-Wesley Publising Company, 2003) 
[7] Sila, Ibrahimpour. Examining the effects of contextual factors on TQM and performance through the lens of organizational theory: an empirical study, Journal of Operations Management, 25 (1), 2007, 83-109

[8] Gaspersz, Vincent. Total Quality Management (Jakarta: Gramedia Pustaka Umum, 2005)

[9] Corbett, Lawrence M. and Kate N. Rastrick. Quality performance and Organizational Culture: A New Zealand Study, International Journal of Quality \& Reliability Management, 17 (1), 2000, 14-26

[10] Demirbag, M., Tatoglu E., Tekinkus, M. and Zaim, S. An analysis of the relationship between TQM implementation and organizational performance: evidence from Turkish SMEs, Journal of Manufacturing Technology Management, 17 (6), 2006,829 47

[11] Brah, S. and Lim, H. The effects of technology and TQM on the performance of logistics companies, International Journal of Physical Distribution \& Logistics Management, 36 (3), 2006, 192-209

[12] Rahman, S. A comparative study of TQM practice and organisational performance of SMEs with and without ISO 9000 certification, International Journal of Quality \& Reliability, 18 (1), 2001, 35-49

[13] Prajogo, Daniel I. and Soon W. Hong. The effect of TQM on performance in R\&D environments: A perspective from South Korean firms, Technovation, 28 (1), 2008, 855-863

[14] Prajogo, Daniel.I., and Brown, A. The Relationship Between TQM Practice and Quality Performance and the Role of Formal TQM Programs: An Australian Empirical Study. Quality Management Journal, 11(4), 2004, 31-42

[15] Prajogo, Daniel I., and Christopher M. McDermott. The relationship between total quality Management practices and organizational culture. International Journal of Operations \& Production Management, 25 (11), . 2004, 1101-1122

[16] Salaheldin, Ismail Salaheldin. Critical success factors for TQM implementation and their impact on performance of SMEs. International Journal of Productivity and Performance Management, 58 (3), 2009, 215-235

[17] Munizu, Musran. Analisis Persepsi Karyawan atas Keberhasilan Pelaksanaan Gugus Kendali Mutu (GKM) pada Karyawan Produksi Pabrik Karung (PK) Rosella Baru, PTPN XI (Persero) Surabaya. Tesis. Program Pasca Sarjana Unair, Surabaya, 2002.

[18] Sugiyono. Statistik Untuk Penelitian (Bandung, Indonesia: Alfabeta, 2008)

[19] Badan Pusat Statistik Kota Makassar dalam Angka, (Makassar: BPS Press, 2011)

[20] Cooper, Donald R. Dan C.William Emory. Business Research Methods (Chicago USA: Richard D. Irwin, 1999)

[21] Sekaran, Uma. Research Methods for Business (Carbondale, USA: Southern Illinois University, 2007)

[22] Hair Jr., Yoseph F., Rolph E. Anderson, Ronald L. Papham, William Black. Multivariate Data Analysis (NJ USA: Prentice-Hall, 1998)

[23] Ferdinand, Augusty. Structural Equation Modeling dalam Penelitian Manajemen (Semarang, Indonesia: Universitas Diponegoro Press, 2002) 